\title{
Scraping marking behaviour of the largest Neotropical felids
}

\author{
Francisco Palomares ${ }^{\text {Corresp., }}{ }^{1}$, Noa González-Borrajo ${ }^{1}$, Cuauhtémoc Chávez ${ }^{2}$, Yamel Rubio ${ }^{3}$, Luciano M \\ Verdade $^{4}$, Rocio Monsa ${ }^{4}$, Bart Harmsen ${ }^{5}$, Begoña Adrados ${ }^{1}$, Marina Zanin ${ }^{6}$ \\ 1 Department of Conservation Biology, Estación Biológica de Doñana, CSIC, Seville, Seville, España \\ 2 \\ 3 Escuela de Biología, Universidad Autónoma de Sinaloa, Sinaloa, Mexico \\ 4 Núcleo Laboratorial de Ecologia Evolutiva Aplicada, Universidade de São Paulo, CENA, Piracicaba, Sao Paulo, Brazil \\ 5 Panthera, New York, USA \\ 6 Departamento de Biologia, Universidade Federal do Espírito Santo, Vitória, Espírito Santo, Brazil \\ Corresponding Author: Francisco Palomares \\ Email address: ffpaloma@ebd.csic.es
}

Background. Details of how, why and in what conditions large felids make scrapes is unknown. Here, we examined the general hypothesis about the use of scrapes for marking proposals, as well as to communicate with other individuals to signalize particular points or areas of interest, by studying scrapemarking behaviour of jaguars and pumas.

Methods. We surveyed by scrapes between five days and two months mainly during dry season in five study areas from Mexico (El Edén and San Ignacio), Belize (Cockscomb) and Brazil (Angatuba and Serra das Almas), which differed in presence and/or abundance of jaguars and pumas. Paths were slowly walked for searching for scrapes for teams normally composed by two people and tracks stored in GPS, distinguishing the type of path surveyed (unpaved track roads, trails and cross-country).

Results. We found a total of 269 felid scrapes along $467 \mathrm{~km}$ of paths surveyed, obtaining a finding rate of 0.576 scrapes per $\mathrm{km}$. Most scrapes were found in car tracks ( 0.629 scrapes per km), followed by trails ( 0.581 scrapes per $\mathrm{km}$ ), and rarely we found scrapes in cross country ( 0.094 scrapes per $\mathrm{km}$ ). In trails, scrapes were found in a similar frequency in the centre and edge, whereas in car tracks they were mainly found in the edge. There were also clear differences in the position of the scrapes between study areas that differed in presence and/or abundance of pumas and jaguars, with scrapes located mainly in the centre in areas only with pumas, in the centre and in the edge in areas with a similar number of jaguars and pumas, and in the edge in area mainly dominated by jaguars. The remarking rate tended to be higher in one of the areas with only pumas where natural vegetation was scarcer. Felids chose sites mainly covered by leaves and located in paths less wide, clean and rarely used.

Discussion. Scraping was a frequent behaviour in the largest felids of America, although in some areas, scraping behaviour was rare. Scrapes seem to be signalizing some specific areas within territories and data suggest that they are made with the proposal of communication between individuals. It seems that a high scraping behaviour in pumas is not related to the presence of jaguars. 


\section{Scraping marking behaviour of the largest Neotropical felids}

2 Francisco Palomares ${ }^{1 *}$, Noa González-Borrajo ${ }^{1}$, Cuauhtémoc Chávez ${ }^{2}$, Yamel Rubio ${ }^{3}$, Luciano

3 M. Verdade ${ }^{4}$, Rocío Monsa ${ }^{4}$, Bart Harmsen ${ }^{5}$, Begoña Adrados ${ }^{1}$ and Marina ${ }^{6}$ Zanin

$4{ }^{1}$ Department of Conservation Biology, Doñana Biological Station, CSIC, E-41092 Seville, Spain

5 2Universidad Autónoma Metropolitana-Unidad Lerma, Hidalgo Pte. 46, Col. La Estación,

6 Lerma, Estado de México, 52006, México

7 32Universidad Autónoma de Sinaloa, Escuela de Biología, Culiacán Rosales, Sinaloa, México

$8{ }^{4}$ Universidade de São Paulo, CENA, Núcleo Laboratorial de Ecologia Evolutiva Aplicada, P.O.

9 Box 96, Piracicaba, SP 13416-000, Brazil

10 5Panthera, 8 West 40th Street, 18th Floor, New York, NY 10018, USA and 4 Environmental

11 Research Institute, University of Belize, UB preschool Grounds, Price Centre Road, PO box 340,

12 Belmopan, Belize

13 'Departamento de Biologia, Universidade Federal do Espírito Santo, Centro de Ciências

14 Humanas e Naturais, Vitória, Espírito Santo, Brazil

15 Corresponding author:

16 Francisco Palomares ${ }^{1}$

17 Email address: ffpaloma@ebd.csic.es 
20 Background. Details of how, why and in what conditions large felids make scrapes is unknown.

21 Here, we examined the general hypothesis about the use of scrapes for marking proposals, as

22 well as to communicate with other individuals to signalize particular points or areas of interest,

23 by studying scrape-marking behaviour of jaguars and pumas.

24 Methods. We surveyed by scrapes between five days and two months mainly during dry season

25 in five study areas from Mexico (El Edén and San Ignacio), Belize (Cockscomb) and Brazil

26 (Angatuba and Serra das Almas), which differed in presence and/or abundance of jaguars and

27 pumas. Paths were slowly walked for searching for scrapes for teams normally composed by two

28 people and tracks stored in GPS, distinguishing the type of path surveyed (unpaved track roads,

29 trails and cross-country).

30 Results. We found a total of 269 felid scrapes along $467 \mathrm{~km}$ of paths surveyed, obtaining a

31 finding rate of 0.576 scrapes per $\mathrm{km}$. Most scrapes were found in car tracks (0.629 scrapes per

$32 \mathrm{~km})$, followed by trails (0.581 scrapes per $\mathrm{km})$, and rarely we found scrapes in cross country

33 (0.094 scrapes per $\mathrm{km})$. In trails, scrapes were found in a similar frequency in the centre and

34 edge, whereas in car tracks they were mainly found in the edge. There were also clear differences

35 in the position of the scrapes between study areas that differed in presence and/or abundance of

36 pumas and jaguars, with scrapes located mainly in the centre in areas only with pumas, in the

37 centre and in the edge in areas with a similar number of jaguars and pumas, and in the edge in area mainly dominated by jaguars. The remarking rate tended to be higher in one of the areas with only pumas where natural vegetation was scarcer. Felids chose sites mainly covered by leaves and located in paths less wide, clean and rarely used. 
41 Discussion. Scraping was a frequent behaviour in the largest felids of America, although in

42 some areas, scraping behaviour was rare. Scrapes seem to be signalizing some specific areas

43 within territories and data suggest that they are made with the proposal of communication

44 between individuals. It seems that a high scraping behaviour in pumas is not related to the

45 presence of jaguars.

\section{Introduction}

48 Communication plays an important role in mammalian populations and communities, providing,

49 for instance, information about the presence, identity, health or social status of individuals of the same or different species, or location of feeding places within territories and their limits (Johnson, 1973; Mellen, 1993; Gosling and Roberts, 2001). Mammals use visual, tactile, vocal or olfactory signals to communicate to each other or signalizing the area (Reiger, 1979; Macdonald, 1980; Gorman and Trowbridge, 1989), and particularly in carnivore mammals, scent marking

54 using urine, secretions, ground scratching, rubbing, or faeces has been well-documented (Asa et al. 1985; Smith et al. 1989; Barja et al. 2005). Solitary carnivores have spatially dispersed

56 populations and indirect scent-marking signals are the most frequently via of intraspecific and

57 interspecific communication. Among the types of indirect marking signals, scratches present the

58 characteristics of functioning both as visual and olfactory signals, since the ground is removed and odour is added from the paw glands (Schaller, 1972; Peters and Mech, 1975; Bekoff, 1979).

61 Jackson and Ahlbom, 1988; Ghoddousi et al. 2008). However, detailed description of this

62 marking behaviour, and how and in what conditions felids make scrapes, and the intention of 
63 felids behind scraping behaviour, are largely unknown and untested in most species and

64 situations (but see Smith et al. 1989; Harmsen et al. 2010a; Allen et al. 2014). Scrapes are

65 depressions in the ground made by felids with their hind legs, moving back the dirt and making a

66 pile of it at the end of the scrape (Smith et al. 1989; Harmsen et al. 2010a; Logan and Sweanor,

67 2010; Fig. 1), although in occasions the front leg may also be used (Harmsen et al. 2010a).

68 Scrapes seem to be regularly created along territorial boundaries or prominent travel-ways

69 (Seidensticker et al., 1973; Logan and Sweanor, 2010; Harmsen et al. 2010a). At least in pumas,

70 most of them are thought to be made primarily by mature males and less often or not at all by

71 mature females or inmature individuals (Logan and Sweanor, 2010; Harmsen et al. 2010a; Allen

72 et al. 2014). Harmsen et al. (2010a) specifically studied scrape-marking behaviour in jaguars and

73 pumas in one area of Central America, and found that both species scrape, although scrapes were

74 spatially clustered along trails and male pumas were who more often scraped. Moreover, the

75 scrapes tended to be larger in jaguars than in pumas, although not enough to be distinguished

76 only by size.

77 Here, we studied scrapes and the scrape-marking behaviour of jaguars and pumas in several 78 ecologically different areas of Neotropic. We chose for surveys areas with only pumas and other areas with the presence of both species but with different densities of each felid in order to be able to ascertain for a possible interaction between the scrapes morphology and scrape-marking

81 behaviour and the sympatry between both species. We specifically aimed first to describe how 82 scrapes are and the characteristic of the places where scrapes are found, examining if there are differences in scrapes and the scrapping behaviour between areas differing in presence and

84 density of both felids. Secondly, we examined the general hypothesis about both felids species using scrapes for marking proposals, as well as to communicate with other individuals and to 
86 signalize particular points or areas of interest. If so, we expect 1) they will select specific points

87 with particular characteristics which would facilitate other individuals detecting them, 2) the area

88

89

90

91

92

93

94

95

96

97 around the point would present some distinctive general habitat characteristics in relation to other parts of the study area, and 3) scrapes will not have evenly distributed in space and will be concentrated in some given points where re-scraping will be frequent.

\section{Material \& Methods}

Study Areas

We carried out the study mainly in five areas (Fig. 2): 1) two zones around San Ignacio municipality (Mexico), 2) El Edén Ecological Reserve (México), 3) Cockscomb Basin Forest Reserve (Belize), 4) three sites at Angatuba municipality (Brazil), and 5) the Serra das Almas

7 Private Reserve of Natural Heritage (Brazil). The surveyed areas in San Ignacio (23\% $31^{\prime}$ and $24^{\circ}$ $26^{\prime} \mathrm{N}, 105^{\circ} 44^{\prime}$ and $106^{\circ} 44^{\prime} \mathrm{W}$ ) have sandy and clay soils, and are dominated by deciduous and semideciduous tropical forest with some areas of dry tropical forest (Rubio et al. 2010). El Edén $\left(21^{\circ} 13^{\prime} \mathrm{N}, 87^{\circ} 11^{\prime} \mathrm{W}\right)$ located in the State of Quintana Roo, México, mainly has rocky soils and includes a great variety of ecosystems, mainly formed by semideciduous dry tall tropical forest dominated by trees (up to $25 \mathrm{~m}$ ), and tropical short forest (up to $12 \mathrm{~m}$ ) in the lower part, which usually flows during the rainy season, savanna like vegetation with some palm tree also flowed during the rainy season, and secondary regeneration plant communities located in formerly agricultural or cattle areas (Torres-Barragán et al. 2004). Cockscomb (16 $\left.47^{\circ} \mathrm{N}, 88^{\circ} 37^{\prime} \mathrm{W}\right)$, has sandy and clay soils and was heavily logged until the 1980s; in 1990 was declared a wildlife sanctuary. Thus, the vegetation of Cocskomb is composed mainly by well-developed secondary, 
108 moist, broadleaf tropical forest at several stages of succession (Harmsen et al. 2010a; Rabinowitz

109 and Nottingham 1986). Angatuba is located in the south-central region of São Paulo state, and

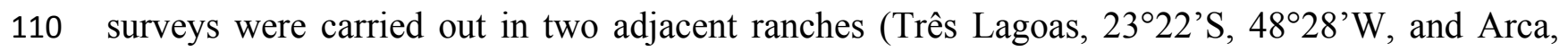

$\left.11123^{\circ} 20^{\prime} \mathrm{S}, 48^{\circ} 27^{\prime} \mathrm{W}\right)$, and in the Angatuba Ecological Station (23⒉ $24^{\prime} \mathrm{S}, 48^{\circ} 21^{\prime} \mathrm{W}$ ), located $9 \mathrm{~km}$

112 from the ranches. Angatuba has sandy soils, a humid subtropical climate, is situated in the

113 transitional region between the Atlantic Forest and Cerrado biomes, and some patches of 114 autochthonous (Cerrado and Atlantic Forest) vegetation remain (Athayde et al. 2015), although 115 most of the area in the ranches, and in lesser extension in the Ecological Station, has been 116 forested with eucalyptus and pine plantations. Serra das Almas is a private protected area located 117 at the Ceará State in the Brazilian Caatinga biome (5॰8'29.15"S; 4054'58.60"W). Three mainly 118 phytophysiognomies of Caatinga biome are found in this reserve: seasonal and dense shrub 119 vegetation, seasonal deciduous thorn forest, and montane seasonal deciduous forest (Araújo and 120 Martins, 1999; Lima et al. 2009).

121 Pumas were the only large felid species present in Serra das Almas and Angatuba, whereas that 122 both species, pumas and jaguars, were present in the other three study areas, although in one of 123 them (Cockscomb) jaguars are much more abundant than pumas (Harmsen et al. 2010b, and see 124 below).

125 We also analysed the faeces or urine we found over scrapes to try to determine species making scrapes (see below), and for this analysis, in addition to the data gathered in our main study 127 areas, we also included other cases obtained along surveys in other areas from Latin-America such as the Viruá National Park in the Amazon basin (Brazil), the Ecological Reserve El Zapotal 129 in Quintana Roo (México), and in Los Ocotones and La Cojolita in Chiapas (México; Fig. 2; 130 details of these surveys and areas in Palomares et al. 2012, 2016). 
132 Surveying for scrapes

133 Surveys lasted between five days and two months, and mainly carried out during the dry season 134 in all study areas, except in El Edén and Cockscomb when samplings also included the transition 135 with the rainy period (in April 2012 San Ignacio, in September-October 2012 in Angatuba, in 136 May-June 2013 in El Edén, in April-June 2014 in Cockscomb, and one in September and another 137 one in November 2015 in Serra das Almas). Paths were only surveyed once except in Serra das 138 Almas that was sampled twice as mentioned). Nevertheless, in El Edén and Cockscomb, we also recorded opportunistically some other scrapes after the first survey since we continued with other activities, which were not considered by estimating finding rates, but they were considered for estimating scrapes size, position in the paths, or re-scraping rate in order to not lose biological information. All paths were slowly walked (about 2-3 km per hour) for searching for scrapes for teams normally composed by two people and tracks stored in GPS, distinguishing the type of path surveyed (unpaved track roads, trails and cross-country). We took attention in looking for scrapes within path limits and in their borders, so when we detected felid tracks leaving the paths we tracked them when possible outside of the path in order to detect additional scrapes outside from it. This was particularly possible in the study areas with sandy substrates such as Angatuba and Serra das Almas.

Most times a scrape was found, their position was recorded with a GPS, along other associated

150 information such as position in the path (centre, wheel tracks, border, outside and faraway; see 151 below), type of substrate (ground or rock), cover of substrate (clean, grass, woody material, 152 leaves), type, height and cover of vegetation around (in a $25 \mathrm{~m}$ diameter circle centred in the 153 scrape), the use of the path by people (habitual, rare or abandoned), and if the path had any kind 
154 of maintenance or not. We did not record if scrapes had single or double rakings as described by

155 Harmsen et al. (2010a; Fig. 1). Scrapes were considered to be in: 1) centre when situated in the

156 space between the wheel tracks for the case of unpaved track roads, or within the walkable part

157 in the case of trails; 2) wheel tracks when just in the tracks left for wheels for the case of 158 unpaved road; 3 ) border, outside or faraway when it was up to $1 \mathrm{~m}$, between $1-5 \mathrm{~m}$, and $>5 \mathrm{~m}$ 159 outside of the workable part of trails or from the wheel tracks of unpaved roads.

160 Additionally, when scrapes were relatively recent and, therefore, size was clearly defined, their 161 length (without the pile of dirt accumulated in the back of scrape) and width were measured (Fig.

162 1). Scrape length was taken at the direction in which the scrape was made by the felids, which 163 could most times easily be distinguished by tracts left by the fingers of animals, and if not by the accumulated dirt on one of the extremes (Fig. 1).

Sampling in Brazil were carried out under licenses no. 11214 and no. 13781 of ICMBio, and $\mathrm{n}^{\circ}$ 131/2005 CGFAU/LIC, 13883-1 SISBIO and 15664-1 SISBIO of the Instituto Brasileiro do Meio Ambiente - IBAMA, and at the Mexican sites under the licence SGPA/DGVS/549 of the Dirección General de Vida Silvestre (Semarnat). Sampling in Belize and posterior exportation of the faeces was given by the Forest Department of Belize with the Ref. No. CD/60/3/14 (25). Faecal samples were exported from Brazil to Spain for genetic analysis under IBAMA/CGEN Autorização de Acesso licence $n^{\circ}$ 063/05 and IBAMA/CITES export licences $n^{\circ} 0123242 B R$, 08BR002056/DF and 09BR003006/DF, and from Mexico to Spain under the export licences $\mathrm{n}^{\mathrm{o}}$ 173 MX33790 and MX42916 of the Secretaria de Medio Ambiente/CITES. 
176 We examined if there was any kind of selection of the points used for scrapping at two different

177 scales. First, we tested the selection at the microsite scale of the scrape (i.e. substrate type and

178 ground cover), in a plot of $1 \times 1 \mathrm{~m}$ side situated around the scrape, and compared it with what

179 had in another $1 \times 1 \mathrm{~m}$ plot situated just $5 \mathrm{~m}$ further on the same path walked. The distance of $5 \mathrm{~m}$

180 was arbitrarily chosen on the basis of being enough far to present a random sampling of the

181 characteristics of the ground in the path, but enough close to be sure conditions of the path were

182 similar. Within each $1 \mathrm{~m}$ plot we estimated the percentage of clean ground or covered by grass,

183 leaves, rocks, or woody material. Second, we looked if the path and vegetation characteristics of

184 the scrapes presented any particular features (path use, width and maintenance, and vegetation

185 height, cover and type). These data were compared with their availability in the study area,

186 which was obtained by sampling these same variables every $500 \mathrm{~m}$ on the paths surveyed for

187 scrapes. The vegetation types considered for each study area were Atlantic Forest, Cerrado, and

188 plantations (eucalypt and pine altogether) in Angatuba; savannas, tall forest, short forest and 189 secondary forest (regeneration forest) in El Edén; and tall forest and secondary forest in

190 Cockscomb. In many occasions the paths were located just in the join border of two vegetation

191 types, so we independently recorded vegetation in each side of the path, and considered it as

192 edge for analysis. Vegetation characteristics were measured in a $25 \mathrm{~m}$ diameter circle centred in 193 the scrape.

195 Felid relative abundance and assigning scrapes to species and sex

196 We got an index of jaguar and puma relative abundance (ratio jaguar/puma faeces) in each study 197 area by collecting faeces in the same tracks where scrapes were recorded. 
198 On the other hand, when we found faeces or urine over scrapes we collected a piece of the faeces

199 or the leaves with urine in order to identify the species and the sex of individual that deposited 200 them.

201 Faeces and urine were analyzed by non-invasive molecular techniques previously developed in 202 our lab (see Roques et al. 2011, 2014 for further details). Although we cannot be sure about the 203 faeces or urine found over scrapes necessarily had to come from the species and individuals who 204 made the scrape, we considered relevant to include this information. As mentioned previously in 205 the study are section, for this analysis, in addition to the data gathered in our main study areas, 206 we also included other cases obtained along surveys in other areas from Latin-America or in 207 other samplings of the same areas.

Data analysis

210 We could not get all measures and variables for all study areas, so for each analysis we will

211 indicate for which areas data were available. Similarly, since there were many different types of 212 data and comparisons, the statistical analysis performed will be mentioned in the appropriate part 213 of the result section.

214 Linear distribution of scrapes on paths was described by determining first the number of scraping 215 sites and the rate of re-scraping per site (i.e. the number of scrapes found in each site). A site was 216 defined as an area where one or more scrapes were found within a given distance. To determine 217 this distance, we used the maximum distance we found $(21 \mathrm{~m})$ between scrapes in two intensive 218 scrapping sites that we found in the Angatuba area. Therefore, scrapes were considered as 
219 belonging to the same site if distance was equal or inferior to $21 \mathrm{~m}$. We are aware this distance of

$22021 \mathrm{~m}$ might not be the same for all study areas and situations, but it is the only objective

221 information we had about this issue. Furthermore, we also counted the number of scrapes we

222 found between 0 and $21 \mathrm{~m}$, between 22 and $100 \mathrm{~m}$, between 101 and $500 \mathrm{~m}$, and further than 501

$223 \mathrm{~m}$, in order to be able to recognize if there were different patterns of linear distribution of scrapes

224 among study areas. These distance intervals were somewhat arbitrarily chosen, but according the

225 range of home range sizes of jaguars and pumas (see González-Borrajo et al. 2017), is reasonable

226 to think that they represent scrapes made in the same site, in the same area, in a relatively close

227 distance to another scrape, and in an isolated way, respectively.

228 Additionally, we determined if scrapes were spatially aggregated or randomly distributed on

229 trails in each study area by the Ripley's reduced second moment function K(r) from a point

230 pattern in a window and the translation correction (Dixon, 2002; Ohser, 1983). To adapt the

231 Ripley's function to our specific case where scrapes were looked in linear transects instead of

232 areas, we considered as window the effective searching area of each study site, which was

233 formed by the total sampled transects with a width of $22 \mathrm{~m}$. Therefore, the Ripley's function

234 examines how distance between scrapes varied along the distance sampled in trails, and the

235 curve formed by the Ripley's function may inform on the patterns of linear spatial distributional

236 of scrapes on trails. To statistically test if the observed distribution of scrapes was significantly

237 different from a random distribution, we generated 1000 data set of random positions of the same

238 number to this of observed scrapes in each study area, and looked if the observed Ripley's

239 function overlapped or not with the expected ones. If the observed Ripley's function is above the 240 expected ones it would indicate that scrapes were close together than expected by random. The 
241 analysis was performed with the 'spatstat' package (Baddeley and Turner, 2005) in the R

242 software (R Core Team, 2016).

243

244 Results

245 Field samplings and finding rate

246 We walked $467 \mathrm{~km}$ of paths once or more times, finding a total of 349 felid scrapes, considering

247 those found during surveys for scrapes (269) and those found while carrying out other activities

248 (80). Considering for all areas only scrapes found during the specific samplings for scrapes (269

249 scrapes), we found a scraping rate of 0.576 scrapes per $\mathrm{km}$ surveyed (Table 1). The intensity of 250 scraping behaviour differed among study areas and type of path. The highest number of scrapes

251 was found in Angatuba, but once corrected by kilometers surveyed, Serra das Almas was the 252 area where finding rate was higher, followed by El Edén, Angatuba, Cockscomb, and San

253 Ignacio where only two scrapes were found in $67 \mathrm{~km}$ surveyed $\left(X^{2}=37.90\right.$, d.f. $=4, p<0.001$;

254 for differences among study areas; Table 1). Due to the low number of scrapes found in San

255 Ignacio, we did not consider this area for further analysis. Scrapes were not found with the same 256 probability in all types of path surveyed $\left(X^{2}=12.64\right.$, d.f. $\left.=2, p=0.002\right)$. Most scrapes were

257 found in car tracks (finding rate $=0.629$ scrapes per $\mathrm{km})$, followed by trails $(0.581$ scrapes per $258 \mathrm{~km})$, and rarely we found scrapes in cross country (0.094 scrapes per km; Table 1). Differences 259 between car tracks and trails were not statistically significant $\left(X^{2}=0.17, d . f .=1, p=0.685\right)$.

261 Position of scrapes in paths 
262 Most scrapes were found in the border (43.7\%) and centre (27.4\%) of paths, although they also

263 were recorded far away (15.7\%), in the wheel car path (7.2\%), and outside $(6.0 \%)$ of the path (n

$264=318$ scrapes with information). It is noteworthy the relatively high number of scrapes found far

265 away from paths, but data are biased because we found two high intensive scrapping zones just

$266 \quad 15-25 \mathrm{~m}$ from the edge of a car tracks and separated in between by $157 \mathrm{~m}$ in the Angatuba study

267 area, where a total of 49 (39 plus 10, respectively) out of 96 scrapes found in the area were in

268 these two points (Fig. 3). The two intensive scraping points covered a surface of 54 and $44 \mathrm{~m}^{2}$,

269 respectively, between their most further scrapes and could be located after tracking a puma for

270 approximately $800 \mathrm{~m}$ that was moving by the car tracks and entered to this area (Fig. 3). This

271 area was used during all the duration of the study and even still used three years later when we

272 visited the study area again. We set a camera track in the area and two days later we recorded a

273 male puma making two consecutive scrapes with the hind legs (Supplementary material section).

274 He was in scrapping behaviour during 42 seconds and took 18 and 16 seconds in each scrape; he

275 also deposited a small fecal substance after the first scrape. Three years later, we set another

276 camera trap in the same point during four weeks, and we recorded four different pumas (two

277 adult males, one adult female, and one individual of undetermined sex) visiting the point. Apart

278 from these two intensive scraping sites, only one scrape was located far away from paths. For

279 further analysis, these two intensive scrapping sites will be considered as two data points if not 280 otherwise indicated.

281 By type of path, considering data from all study areas altogether scrapes were found in a similar 282 frequency in the centre and edge of trails, whereas they were mainly found in the edge in car 283 tracks (Fig. 4). But the most interesting was that there were clear differences between study areas 284 (trails: $X^{2}=45.02$, d.f. $=2, p<0.001$; car tracks: $X^{2}=37.02$, d.f. $=6, p<0.001$; data from edge 
285 and outside grouped for analysis in both cases; Fig. 4). In the areas with only pumas (Angatuba

286 and Serra das Almas), scrapes were mainly found in the centre of the paths when these were

287 trails, and in the wheel tracks when paths were car tracks. However, in the areas with jaguars and

288 pumas, most scrapes were found in the centre or edge (El Edén), or in the edge (Cockscomb)

289 when trails, and in the edge when car tracks in both areas (Fig. 4).

290

291 Re-marking rate and linear distribution of scrapes on paths

292 We recorded a total of 347 scrapes located in 207 scraping sites (i.e. $<22 \mathrm{~m}$ far from each other),

293 with a mean of $1.44(\mathrm{SD}=2.63$, range $=1-39)$ scrapes per site. If we removed from analysis the

294 two intensive scraping sites found in Angatuba, the mean number of scrapes per site was 1.23

$295(\mathrm{SD}=0.61$, range $=1-5)$, and the Kruskal-Wallis test suggested differences between study areas

$296(H=7.375$, d.f. $=3, p=0.061)$, tending the number of scrapes per site to be slightly higher in

297 Angatuba than in the other three areas (Fig. 5).

298 The representation of the Ripley's function showed a similar pattern in scrape distribution on 299 trails between El Edén and Serra das Almas, and different ones in Angatuba and Cockscomb, but 300 in all cases scrapes were clearly aggregated on trails, except in the Angatuba area when they 301 were found according a random distribution when distance between scrapes was higher than $3023000 \mathrm{~m}$ (Fig. 6). Overall, about $40 \%$ of scrapes were found in distances between 100 and $500 \mathrm{~m}$ 303 far from each other, whereas scrapes very close $(<22 \mathrm{~m})$, in the same areas (between $22-100 \mathrm{~m})$, 304 or separated by $>500 \mathrm{~m}$ were found in similar frequencies (around $20 \%$; Fig. 7). However, the 305 chi-square test detected significant differences among study areas $\left(X^{2}=33.20\right.$, d.f. $=9, P<$ 306 0.001), and in Angatuba, scrapes were more frequently found in close proximity (i.e. re-scraping 307 behaviour in the same site was high; data from the two intensive scrapping sites removed for 
308 analysis), and in Cockscomb, felids made scrapes every 100-500 m with some re-scraping

309 behaviour along transects, but also large sections $(>500 \mathrm{~m})$ of paths without scrapes (Fig. 7).

310 Linear distribution of scrapes in El Edén and Serra das Almas, however, was not statistically

311 different (Fig. 7), with scrapes mainly found every 100-500 m, although there also were large

312 sections $(>500 \mathrm{~m})$ of paths without scrapes.

314 Characteristic of sites with scrapes

315 Felids made scrapes on sites mainly covered by leaves (88 cases; Fig. 1), and in less extension on

316 sites with grass (five cases), no coverage (three cases) or woody material (one case) in the area of

317 Cockscomb, and on sites mainly covered by leaves (58 cases), but also with no coverage (11

318 cases) or woody material (one case) in El Edén. When we compared the materials covering the

$3191 \mathrm{x} 1 \mathrm{~m}$ plots where scrapes were made, with the paired $1 \mathrm{x} 1 \mathrm{~m}$ plots situated $5 \mathrm{~m}$ away from

scrapes to test for any kind of selection, we found that whereas in Cockscomb felids did not

321 show any kind of selection, in El Edén they preferred to make scrapes in sites with leaves and

322 without stones and grass (Table 2).

323 For all study areas with data, felids preferred for scrapping paths less wide (between 1.7 and 3.0

$324 \mathrm{~m}$, depending of the study area), clean paths and rarely used (except for Cockscomb, where they

325 preferred frequently used paths) than available; abandoned paths were used less than available

326 (Table 3). On the other hand, scrapes were preferably found in tall and short forest and less than

327 expected in savanna and secondary forest in El Edén, in tall forest in Cockscomb (practically the

328 only available habitat type), and preferably in natural vegetation (Atlantic Forest and Cerrado)

329 and less than expected in edges of vegetation types and plantations in Angatuba (Table 3). In 
330 scrapping sites, vegetation height was shorter in Angatuba and taller in Cockscomb and El Edén

331 than available, and vegetation cover was higher in Angatuba than available, but according

332 availability in Cockscomb and El Edén (Table 3).

334 Size of scrapes

335 For a total of 202 scrapes from Angatuba, Cockscomb and El Edén width and length were

336 measured. Width and length of the scrapes ranged between 10-36 cm and 14-88 cm, respectively,

337 covering a total surface of $200-2464 \mathrm{~cm}^{2}$. Width and length were, on average, $21 \mathrm{~cm}$ and $25 \mathrm{~cm}$,

338 respectively, being this last measure more variable than the first $(S D=4.7$ and 10.6,

339 respectively). On average, the ratio length/width was $1.23 \pm 0.56 \mathrm{SD}$ (range=0.53-4.35).

340 However, univariate Kruskall-Wallis tests detected significant differences among study areas,

341 being as a rule, scrapes shorter and wider in El Edén than in the other two study areas $(H=$

34230.014 and 24.574, respectively, $d . f .=2, p<0.001$ in both cases; Fig. 8). The area where jaguars

343 were absent (Angatuba) presented the intermediate values in scrape sizes (Fig. 8).

344 It is interesting to note that in Angatuba, where jaguars were absent, variability of data in scrape

345 width was markedly higher than in the other two areas, fact that did not happened for length (Fig.

346 8). Furthermore, outsider values were mainly observed in Cockscomb for scrape length, and in

347 lesser extend in El Edén, where both jaguars and pumas are present (Fig. 8). Additionally, most

348 of these scrapes with outsider long sizes (approximately $>40 \mathrm{~cm}$; Fig. 8) presented higher

349 length/width ratios (mean length/width ratio of outsiders $=2.74 \pm 0.90 . \mathrm{n}=13$ ) than the average

$350(1.26 ; \mathrm{n}=201, \mathrm{p}=0.04)$. Furthermore, in all these 13 scrapes it was not clear the signal of two 
351 legs on the ground (Fig. 1). All this information suggests that these scrapes could be made by

352 jaguars and probably with the front legs instead the hind legs.

353

354 Scrapes by species and sex, and relative abundance of each species

355 In 43 scrapes, faeces or urine, respectively, were found over scrapes, and in 32 cases (31 faeces

356 and one urine) the felid could be identified (Table 4). Faeces were from jaguars in 21 scrapes (18

357 from males, one from female and two undetermined sex) from Viruá, Los Ocotones, El Edén and

358 Cockscomb. Nine faeces were from pumas (all from males) from Viruá, El Zapotal, El Edén,

359 Serra das Almas and Angatuba, and the only urine sample identified come from a puma in La

360 Cojolita (Table 4). One faeces sample was identified as ocelot (Table 4).

361 As expected in Antaguba and Serra das Almas we did not find faeces from jaguars, finding 26

362 and 34 faeces from pumas, respectively. In the other three study areas faeces from both species

363 were found with ratios jaguar/puma of 0.4, 1.6 and 11.3 for San Ignacio, El Edén, and

364 Cockscomb, for a total of 40,50 and 37 faeces collected of both species in each study area, 365 respectively.

367 Discussion

368 Scraping encounter rates

369 Scraping was a frequent behaviour in the largest felids of America. Aproximately, one scrape per

$3701.5 \mathrm{~km}$ was found when walking by unpaved track roads or trails in most study areas.

371 Nevertheless, in some areas such as the dry forest of San Ignacio (northern Mexico), scraping 
372 behaviour seemed to be rare. This last result is particularly surprising as pumas were more

373 abundant than jaguars and reported in many different areas and habitats (previously and

374 confirmed by this study too), as a felid which scraping behaviour is frequent (Harmsem et al.

375 2010a; Logan and Sweanor, 2010; Allen et al. 2014). In other areas from Amazon basin, we

376 found an apparently low scraping behaviour for any species (F. Palomares, pers. obser.), while

377 surveying for faeces (Palomares et al. 2012, 2016). In other areas such as the Pantanal, jaguars

378 also seem to scrape infrequently (Schaller and Crawshaw, 1980). Thus, the factors promoting a

379 noticeable scrapping behaviour in the largest felid of America is not related with their abundance

380 or possible presence of one or both species, and some characteristics of the areas where they live

381 might explain the observed differences.

383 Site selection for scrapping

384 It was clear that felids liked to scrape in well delimited and clean paths, independently if these

385 were trails or unpaved track roads, avoiding somewhat sites without trails (but see Seidensticker

386 et al. 1973, for a contrasting result for pumas in Idaho). Furthermore, they preferred paths rarely

387 used although not abandoned ones, as the abandoned one use to have abundant plant

388 regeneration and/or tall grassy vegetation, making, on one hand, more difficult for felid to move

389 through them, and, on other one, to succeed with the objective of signalling the path. Although in

390 some well protected areas, such as Cockscomb, they preferred the more frequently used paths,

391 which are also used for tourist visitation during daylight. Nevertheless, it is interesting to note

392 that this area has a long protection history and tourist visitation, so animals may be relatively

393 used to people, in addition to the chance of encounters with people is smaller due to the 
394 crepuscular and nocturnal activity habits of felids in the area (Harmsen et al. 2010b). It is also 395 interesting to note that the only two intensive scraping sites detected were at $15-20 \mathrm{~m}$ further 396 from the paths. Maybe animals prefer to do these so intensive scraping sites slight far from paths, 397 but it might simply be a consequence about roads or trails are periodically managed and trodden, 398 and this might prevent the accumulation of scrapes. In fact, on paths of one or other type we

399 found a similar number of scrapes close together (what was called as clustered scrapes by 400 Harmsen et al. 2010a o community scrapes by Allen et al. 2014). We found no report with so 401 intensive scraping sites as those found in Angatuba in this study.

402 Scrapes seemed to be also done to signalizing other elements of the habitats within territories. In 403 addition to the result obtained on scrape aggregation and re-scrapping behaviour, which suggest 404 animals are intentionally marking some given sites and/or habitats, somewhat, scrapes were not 405 made at random and felids selected specific sites to make scrapes both at substrate (microsite) scale and regarding the site level. Selection on microsite scale seemed to be conditioned by the

407 type of substrate that would facilitate signal detection. Felids showed preferences by sites with 408 leaves, and avoid sites with grass and stones, and with a rocky substrate. Stones might make scraping more difficult and less detectable. As a matter of fact, in areas with no rocky substrate, we did not detect selection of any particular microsites.

411 On the other hand, as a rule, felids did not evenly scrape in all types of vegetation found in the study areas, and the pattern seemed to be also different between study areas according to the 413 main types of vegetation found. In the two more natural areas such as Cockscomb and El Edén, 414 felids selected the more natural and developed vegetation types among available, although they 415 avoided the natural savanna habitat in El Edén. In Angatuba, pumas also selected the natural 416 habitats (Atlantic Forest and Cerrado) and clearly avoided plantations. Therefore, it seems clear 
417 felids concentrate scrapes in the best quality areas within their home ranges. This hypothesis is

418 also supported by the linear distribution of scrapes. In the area more altered and heterogeneous

419 (Angatuba), re-scraping behaviour was higher. However, in the more homogeneous area

420 according habitat quality (Cockscomb), distribution of scrapes was more uniform and scrapes

421 were mainly situated in regular interval of 100-500 m. Finally, in the two areas where there were

422 some level of regeneration of the natural vegetation (El Eden, and Serra das Almas), patterns of

423 linear distribution of scrapes were similar, with scrapes regularly spaced every 100-500 $\mathrm{m}$ or

424 isolated (i.e. scrapes situated $>500 \mathrm{~m}$ in between). These results suggest that felids mainly

425 concentrate scrapping behaviour in the best natural available habitat types, and so scrapes would

426 be related to the use of optimal habitats (e.g., by higher prey availability and/or better refuges

427 against disturb).

429 Scrapes as a communication tool

430 Our data suggest that scrapes are made with the proposal of communication between individuals.

431 First, the use of well delimited paths for scraping is already pointing in that direction. Felids in

432 general, and jaguar and pumas in particular, like to move on well-established paths (Harmsen et

433 al. 2010b; Palomares et al. 2012), so they are scraping where there is a higher probability that

434 other individuals or themselves can find the mark. Secondly, they sometimes left faeces or urine

435 on scrapes, and both stuff may inform other individuals about sex, health, and reproductive and

436 social status of individuals (Allen et al. 2014), which reinforced the role of scrapes as a way of

437 intraspecific communication. Third, re-scraping behaviour in some given sites that are visited by

438 several different individuals, suggests this communication role, fact confirmed by Allen et al. 
$439(2014,2015)$ with pumas. Thus, it is also quite probably that intensive scraping sites could be

440 situated in contact borders between territories or to signalize important resources (Seidensticker

441 et al. 1973; Smith et al. 1989), although our data did not allow testing for this possibility.

443 Who scrapes and differences in scrapes and scraping behaviour between jaguar and pumas

444 Our data suggest that both jaguars and pumas make scrapes and that scrapping behaviour in 445 female seems to be a rare event (but see Allen et al. 2014). In fact, we only found a jaguar female 446 faeces on one scrape and in some occasions, we have been able to track male pumas

447 (distinguished by footprint size and phototrapping) finding associated several scrapes, whereas it 448 has never been the case when a female was tracked. However, we can be sure that female pumas 449 visited scraping sites as a couple of them were photographed several times in one of the intensive 450 scraping sites detected in the Angatuba study area. This conclusion is in agreement with previous 451 studies (Seidensticker et al. 1973, Logan and Sweanor, 2010, Harmsen et al. 2010a and Allen et 452 al. 2014). However, Allen et al. (2014) confirmed that mature females also scrape, although 453 much less frequently than mature male pumas (Allen et al. 2015). In addition, we cannot discard 454 that some of the smaller scrapes found in this study come from ocelots since in other areas not 455 sampled for scrapes in some occasion we have observed small scrapes associated with ocelot 456 tracks (F. Palomares, pers. observ.).

457 Our data indicates a human observer cannot distinguish between jaguar and puma scrapes based 458 only in morphology differences. Scrape size of both species widely overlaps. Harmsen et al. 459 (2010a) found similar results in one of our study areas (Cockscomb), although when faeces were 460 over the scrape, they also found that in general scrapes with jaguar faeces were larger than 
461 scrapes with puma faeces. Despite the large overlap in the size of scrapes of both species, our 462 data indicate that jaguars made longer scrapes with constant width, which were not found in the 463 areas with only pumas (Fig. 8). Such scrapes were often single scrapes as defined by Harmsen et 464 al. (2010a). In fact, we did not find single scrapes in the areas with only pumas as also reported 465 by Allen et al. (2014).

466 Other aspect that differentiate jaguar and puma scraping behaviour is position on the paths.

467 When only pumas were in an area (Angatuba and Serra das Almas), scrapes were mainly found 468 on the footable part of the paths (trail centre and wheel tracks on unpaved road), whereas in the 469 areas with jaguars, most scrapes were mainly found in the edge of the path (Cockscomb) or on 470 the edge and centre (El Edén). Note, that in Cockscomb jaguars seem to be much more abundant 471 than pumas (ratio jaguar/puma faeces was 11.3), whereas in El Edén was just slightly higher for 472 jaguars $($ ratio $=1.6)$.

473 Scraping rate was lower in the area where, according to our data on genetic identification of 474 faeces, pumas were less abundant (Cockscomb), and higher in one of the areas with only puma 475 presence (Serra das Almas). Furthermore, in the other area where only pumas were present 476 (Angatuba), scraping rate was not higher than in El Edén (the area with both species present), but 477 this clearly was due to large areas of poor habitat quality (plantations) that were surveyed, where 478 few scrapes were found. However, in this area re-scraping rates were higher than in the other 479 study areas. Thus, it seemed that scraping behaviour was higher in areas with only pumas, and 480 therefore pumas seemed to be the most responsible of scrapes. This result is in agreement with 481 the statements of Schaller and Crawshaw (1980), but it is in opposition to Harmsen et al. 482 (2010a), who suggests that the apparently frequent scraping behaviour of pumas in Cockscomb 483 probably due to jaguar presence in order to use an inconspicuous way of communication between 
484 individuals because of the risk of using a more direct mechanism. If so, they proposed that in 485 areas where pumas were the largest carnivores, scrape rates should be lower. Both in Angatuba 486 and Serra das Almas, where pumas were the largest carnivores, scraping rates were even higher 487 than in Cockscomb. Thus, it seems that a high scraping behaviour in pumas is not related to the 488 presence of jaguars or other larger carnivores.

\section{Conclusion}

491

492

493

494

495

496

497 498

499

500

501

502

503

504

505

In some areas, scraping was a frequent behaviour in both jaguars and pumas, and they were mainly made by males, although pumas seemed to be the most responsible of scrapes. Both felids liked to scrape in well delimited and clean paths, independently if these were trails or unpaved track roads, avoiding somewhat sites without trails. Furthermore, they preferred paths rarely used although not abandoned ones.

Scrapes seemed to be also done to signalizing other elements of the habitats within territories since scrapes were not made at random and felids selected specific sites to make scrapes both at substrate (microsite) scale and regarding the site level. Nevertheless, selection on microsite scale seemed to be conditioned by the type or substrate rather than to facilitating signal detection. Felids selected the more natural and developed vegetation types among available to scrape, and clearly avoided plantations. Thus, scrapes were more patchily distributed in the areas more altered and more evenly distributed in the more natural areas.

Scrapes from jaguar and puma can not be distinguished based only in morphology differences, except for some long scrapes $(>40 \mathrm{~cm})$ that are made by jaguars. The main aspect differentiating jaguar and puma scrapes was its position on the paths, with pumas mostly scraping on the 
506 footable part of the paths (trail centre and wheel tracks on unpaved road), whereas jaguars on the 507 edge of the path, and only jaguars making single scrapes.

508

509 Acknowledgements

510 We thank the managers of the Edén Ecological Reserve (Marco Lazcano), El Zapotal Ecological

511 Reserve (Pronatura Península de Yucatán: Juan Carlos Faller and María Andrade), Fazendas

512 Três Lagoas (Denise Carmignani), Arca (Caetano Carmignani), Estação Ecológica de Angatuba

513 (Bárbara Heliodora Prado), Serra das Almas Natural Heritage Reserve (Thiago Roberto Soares

514 Vieira) for their logistical support. C. Zapata and two anonymous referees made useful 515 comments of the manuscript.

516

517 References

518 Allen M. L., Wittmer H. U. and Wilmers C. C. 2014. Puma communication behaviours:

519 understanding functional use and variation among sex and age classes. Behaviour 151: 819-840.

520 Allen M. L., Wittmer H. U., Houghtaling P., Smith J., Elbroch L. M., and Wilmers C. C. 2015.

521 The role of scent marking in mate selection by female pumas (Puma concolor). PloS one, 10:

$522 \mathrm{e} 0139087$.

523 Araújo, F. S. and Martins F. R. 1999. Fisionomia e organização da vegetação do carrasco no 524 planalto da Ibiapaba, estado do Ceará. Acta Botânica Brasilica 13: 1-13.

525 Asa C. S., Mech L. D. and Seal U. S. 1985. The use of urine, faeces, and anal-gland secretions in 526 scent-marking by a captive wolf (Canis lupus) pack. Animal behaviour 33: 1034-1036. 
527 Athayde, E. A., Cancian L. F., Verdade L. M. and Morellato L. P. C. 2015. Functional and

528 phylogenetic diversity of scattered trees in an agricultural landscape: Implications for 529 conservation. Agriculture, Ecosystems \& Environment, 199: 272-281.

530 Baddeley, A. and R. Turner. 2005. Spatstat: an R package for analyzing spatial point patterns.

531 Journal of Statistical Software 12.6: 1-42.

532 Barja, I. F. J. de Miguel and Bárcena F. 2005. Faecal marking behaviour of Iberian wolf in 533 different zones of their territory. Folia Zoologica 54 : 21-29.

534 Bekoff, M. 1979. Ground scratching by male domestic dogs: a composite signal. Journal of 535 Mammalogy 60: 847-848.

536 Dixon, P. M. 2002. Ripley’s K Function. Encyclopedia of Environmetrics 3: 1796-1803.

537 Emmons, L. H. 1987. Comparative feeding ecology of felids in a neotropical 538 rainforest. Behavioural ecology and sociobiology 20: 271-283.

539 Ghoddousi, A., Hamidi A.K., Ghadirian T., Ashayeri D., Hamzehpour M., Moshiri H, Zohrabi 540 H. \& Julayi L. 2008. Territorial marking by the Persian Leopard (Panthera pardus saxicolor 541 Pocock, 1927) in Bamu National Park, Iran. Zoology in the Middle East, 4: 101-103.

542 González-Borrajo, N., López-Bao J.V. and Palomares F. 2017. Spatial ecology of jaguars, 543 pumas, and ocelots: a review of the state of knowledge. Mammal Review, 47: 62-75.

544 Gorman, M. L. and Trowbridge B. J. 1989. The role of odor in the social lives of carnivores. Pp. 545 57-88 in Carnivore behaviour, ecology, and evolution (J. L. Gittleman, ed.).Springer US.

546 Gosling, L. M. and Roberts S.C. 2001. Scent-marking by male mammals: Cheat-proof signals to 547 competitors and mates. Advances in the Study of Behaviour 30: 169-217. 
548 Harmsen, B. J., Foster R. J., Gutierrez S. M., Marin S. Y. and Doncaster C. P. 2010a. Scrape549 marking behaviour of jaguars (Panthera onca) and pumas (Puma concolor). Journal of 550 Mammalogy, 91: 1225-1234.

551 Harmsen, B. J., Foster R. J., Silver S., Ostro L. and Doncaster C. P. 2010b. Differential use of

552 trails by forest mammals and the implications for camera-trap studies: a case study from 553 Belize. Biotropica, 42: 126-133.

554 Jackson, R. and Ahlborn G. 1988. Observations on the ecology of snow leopard in west Nepal. 555 Pp. 65-87. Proceedings of the 5th International snow leopard symposium. (H. Freeman, ed.). 556 International Snow Leopard Trust and Wildlife Institute of India.

557 Johnson, R. P. 1973. Scent marking in mammals. Animal Behaviour, 21: 521-535.

558 Lima, J. R., Sampaio E. V. S., Rodal M. J. N. and Araújo F. S. 2009. Composição florística da 559 floresta estacional decídua montana de Serra das Almas, CE, Brasil. Acta Botânica Brasilica 23: $560 \quad 756-763$.

561 Logan, K. and Sweanor L. 2010. Behaviour and social organization of a solitary carnivore. Pp. 562 105-117 in Cougar: ecology and conservation (Hornocker, M. and S. Negri, eds.). University of 563 Chicago Press, Chicago, IL,

564 MacDonald, D. W. 1980. Patterns of scent marking with urine and faeces amongst carnivore 565 communities. In Symposia of the Zoological Society of London. 45: 107-139.

566 Mellen, J. D. 1993. A comparative analysis of scent-marking, social and reproductive behaviour 567 in 20 species of small cats (Felis). American Zoologist,33: 151-166. 
568 Ohser, J. 1983. On estimators for the reduced second moment measure of point

569 processes. Mathematische Operationsforschung und Statistik, series Statistics 14: 63-71.

570 Palomares, F., Roques S., Chávez C., Silveira L., Keller C., Sollmann R., Mello do Prado D.,

571 Carignano Torres P., Adrados B., Godoy J.A., De Almeida Jácomo A.T., Mundim Torres N.,

572 Malzoni Furtado M. and López-Bao J.V. 2012. High proportion of male faeces in jaguar

573 populations. PloS one, 7: e52923.

574 Palomares F., Fernández N., Roques S., Chávez C., Silveira L., Keller C. and Adrados B. 2016.

575 Fine-Scale Habitat Segregation between Two Ecologically Similar Top Predators. PloS one 11:

$576 \mathrm{e} 0155626$.

577 Peters R. P. and Mech L. D. 1975. Scent-marking in wolves: Radio-tracking of wolf packs has

578 provided definite evidence that olfactory sign is used for territory maintenance and may serve for

579 other forms of communication within the pack as well. American Scientist 63: 628-637.

580 R Core Team. 2016. R: a language and environment for statistical computing. R Foundation for

581 Statistical Computing. Vienna, Austria. Available at: https://www.R-project.org

582 Rabinowitz, A. R. and B. G. Nottingham. 1986. Ecology and behaviour of the jaguar (Panthera 583 orca) in Belize, Central America. Journal of Zoology 210: 149-159.

584 Reiger, I. 1979. Scent rubbing in carnivores. Carnivore 2: 17-25.

585 Roques S., Adrados B., Chavez C., Keller C., Magnusson W. E., Palomares F. and Godoy J. A. 586 2011. Identification of Neotropical felid faeces using RCP-PCR. Molecular ecology resources 587 11: 171-175. 
588 Roques, S., Furtado M., Jácomo T.A., Silveira L., Sollmann R., Torres N.M., Godoy J.A. and 589 Palomares F. 2014. Monitoring jaguar populations Panthera onca with non-invasive genetics: a 590 pilot study in Brazilian ecosystems. Oryx 48: 361-369.

591 Rubio Y., Bárcenas H. and Beltrán A. 2010. Meseta de Cacaxtla. En Diversidad, amenazas y 592 áreas prioritarias para la conservación de las selvas secas del Pacífico de México (Ceballos, G., 593 L. Martínez, A. García, E. Espinoza, J. Bazaury y R. Dirzo, eds.). F.C.E. México.

594 Schaller, G. B. 1972. The Serengeti lion. University of Chicago Press, Chicago.

595 Schaller G. B. and Crawshaw P. G. Jr. 1980. Movement patterns of jaguar. Biotropica 12: 161596168.

597 Seidensticker J. C., Hornocker M. G., Wiles W. V. and Messick J. P. 1973. Mountain lion social 598 organization in the Idaho Primitive Area. Wildlife Monographs 35: 3-60. Smith J. L. D., McDougal C. and Miquelle D. 1989. Scent marking in free-ranging tigers, 601 Panthera tigris. Animal Behaviour 37: 1-10.

602 Torres-Barragán A., Anaya A. L., Alatorre R. and Toriello C. 2004. Entomopathogenic fungi 603 from 'El Eden Ecological Reserve, Quintana Roo, Mexico. Mycopathologia 158: 61-71.

604

605

606 
608 Figure Legends

609 Figure 1. Examples of scrapes with different sizes and on different substrates. a, b and c are 610 puma scrapes from Angatuba and the other ones could be from pumas or jaguars, although d and

611 f could be from jaguar since they are much longer than wider and no marks from the two legs 612 (see text for details). Mark of claws of both legs (even back leg foot tracks) are clearly 613 appreciated in a and e scrapes. The pile of dirt on the end of the scrape is marked in all cases, and 614 in a and b how length and width were measures indicated as well (note than $\mathrm{b}$ is one case where 615 length and width was similar). Photos by Francisco Palomares.

616

617 Figure 2. Sketch of the principal study areas (Angatuba, Cockscomb, El Edén and Serra das 618 Almas), tracks surveyed (lines) and total scrapes found (points). Details of San Ignacio study 619 area is not showed since only two scrapes were found, and on the general map the location of 620 other areas where we obtained extra information used in this study are indicated with numbers 621 (see "Felid relative abundance and assigning scrapes to species and sex" section).

622

623 Figure 3. Sketch of the two intensive scraping points (ISA1 and ISA2) found after following a 624 puma track in Angatuba study area during the survey of 2012. Aerial imagen obtained from 625 Google Earth (C CNES / Astrium).

626

627 Figure 4. Frequency distribution of the position of the scrapes on trails (A) and car tracks (B) in 628 Angatuba, Cockscomb, El Edén, Serra das Almas and overall. There were no scrapes on trails in 629 Angatuba and on car tracks in Serra das Almas. 
630

631 Figure 5. Mean and standard deviation of the number of scrapes found on the same sites (i.e. $632<22 \mathrm{~m}$ between scrapes) in each study area.

633

634 Figure 6. Estimates of the Ripley's reduced second moment function $\mathrm{K}(\mathrm{r})$, with the translation 635 correction of Ohser (1983), from a point pattern of scrapes in trails sampled in each study area

636 (A-E). The gray shadow represents the expected distribution of scrapes following 1000 random

637 distributions (see text for details). The black lines show the observed distribution of distances

638 between consecutive scrapes. When the line is above the shadow area indicates that scrapes are 639 close together than expected by random.

640

641 Figure 7. Frequency distribution of distances between scrapes on linear paths for every study 642 area and for overall data. There were significant differences between study areas $\left(X^{2}=33.20\right.$, d.f. $643=9, P<0.001$ ), and also between all pair wise comparisons (all $X^{2}>8.53, d . f .=3$, all $P<$ 644 0.036), except between El Edén and Serra das Almas $\left(X^{2}=3.61, d . f .=3, P=0.307\right)$.

646 Figure 8. Box plots show differences in length (A), width (B) and ratio between length and 647 width (C) for scrapes sizes from three study areas. The box indicates the 25 th and 75 th 648 percentiles, a line within the box marks the median; error bars indicate the 90th and 10th 649 percentiles, and point values outside the last percentiles (outsiders). 


\section{Table $\mathbf{1}$ (on next page)}

Scrapes finding rate.

Kilometers surveyed and number of scrapes found in the five study areas and overall by type of path during the first survey in each study area except in Serra das Almas where data from two surveys were considered since the same track $(37 \mathrm{~km})$ was walked and time lap between surveys was 2 months. 
1 Table 1. Kilometers surveyed and number of scrapes found in the five study areas and overall by

2 type of path during the first survey in each study area except in Serra das Almas where data from

3 two surveys were considered since the same track $(37 \mathrm{~km})$ was walked and time lap between

4 surveys was 2 months.

\begin{tabular}{|c|c|c|c|c|c|c|c|c|c|}
\hline \multirow{3}{*}{ Study area } & \multicolumn{6}{|c|}{ Type of path } & \multirow{2}{*}{\multicolumn{3}{|c|}{ Overall }} \\
\hline & \multicolumn{2}{|c|}{ Car tracks } & \multicolumn{2}{|c|}{ Trails } & \multicolumn{2}{|c|}{ Cross country } & & & \\
\hline & $\mathbf{K m}$ & Scrapes & $\mathbf{K m}$ & Scrapes & $\mathbf{K m}$ & Scrapes & $\mathbf{K m}$ & Scrapes & Scrapes/km \\
\hline San Ignacio & 26 & - & 17 & 1 & 24 & 1 & 67 & 2 & 0.030 \\
\hline El Edén & 39 & 16 & 48 & 44 & 5 & 2 & 92 & 62 & 0.674 \\
\hline Angatuba & 171 & 95 & 2 & 1 & 3 & - & 176 & 96 & 0.545 \\
\hline Cockscomb & 33 & 11 & 25 & 16 & - & - & 58 & 27 & 0.466 \\
\hline $\begin{array}{l}\text { Serra } \\
\text { Almas }\end{array}$ & 6 & - & 68 & 57 & - & - & 74 & 57 & 0.770 \\
\hline Total & 275 & 173 & 160 & 93 & 32 & 3 & 467 & 269 & 0.576 \\
\hline
\end{tabular}




\section{Table 2 (on next page)}

Characteristics of microsites with scrapes

Mean and standard deviation of percentages of the soil covered by different materials in $1 \times 1$ $\mathrm{m}$ plots centred in scrapes and $5 \mathrm{~m}$ away in front of the scrape on the path in the study areas of Cockscomb and El Edén. Probabilities of the Mann-Whitney $U$ test statistic to compare the paired $1 \times 1 \mathrm{~m}$ plots are also showed. 
1 Table 2. Mean and standard deviation of percentages of the soil covered by different materials in

$21 \times 1 \mathrm{~m}$ plots centred in scrapes and $5 \mathrm{~m}$ away in front of the scrape on the path in the study areas

3 of Cockscomb and El Edén. Probabilities of the Mann-Whitney U test statistic to compare the 4 paired $1 \times 1 \mathrm{~m}$ plots are also showed.

\begin{tabular}{|c|c|c|c|c|c|c|}
\hline \multirow{3}{*}{ Materials } & \multicolumn{3}{|c|}{$\begin{array}{l}\text { Cockscomb } \\
(n=93)\end{array}$} & \multicolumn{3}{|c|}{$\begin{array}{l}\text { El Edén } \\
(n=65)\end{array}$} \\
\hline & \multicolumn{2}{|c|}{ Mean \pm SD } & \multirow[t]{2}{*}{$\mathbf{P}$} & \multicolumn{2}{|c|}{ Mean \pm SD } & \multirow[t]{2}{*}{$\mathbf{P}$} \\
\hline & Scrape & 5-m-away & & Scrape & 5-m-away & \\
\hline Nothing & $11.8 \pm 21.36$ & $7.0 \pm 17.43$ & 0.092 & $11.3 \pm 22.56$ & $18.4 \pm 29.14$ & 0.242 \\
\hline Grass & $2.7 \pm 11.34$ & $2.7 \pm 11.34$ & 1 & $0.8 \pm 5.10$ & $5.4 \pm 16.40$ & 0.005 \\
\hline Leaves & $85.5 \pm 22.82$ & $90.3 \pm 19.86$ & 0.124 & $78.8 \pm 30.32$ & $66.3 \pm 35.73$ & 0.009 \\
\hline Woody & 0 & 0 & - & $6.8 \pm 16.95$ & $2.9 \pm 10.07$ & 0.209 \\
\hline Stones & 0 & 0 & - & $2.3 \pm 10.68$ & $7.0 \pm 17.65$ & 0.019 \\
\hline
\end{tabular}




\section{Table 3 (on next page)}

Characteristics of the path and vegetation of the sites where scrapes where found.

Characteristics of the path and vegetation of the sites where scrapes where found (Observed) and availability for each study area (Available). Statistical test for comparing the observed and available characteristics are also showed. $\mathrm{ND}=$ no data; $\mathrm{NA}=$ Not available that vegetation type in the study area; Tall/Atlantic forest $=$ it refers to tall forest for Cockscomb and El Edén, and Atlantic forest for Angatuba; Short forest/cerrado= it refers to short forest for El Edén and cerrado vegetation for Angatuba. 
1 Table 3. Characteristics of the path and vegetation of the sites where scrapes where found

2 (Observed) and availability for each study area (Available). Statistical test for comparing the

3 observed and available characteristics are also showed. $\mathrm{ND}=$ no data; $\mathrm{NA}=$ Not available that

4 vegetation type in the study area; Tall/Atlantic forest $=$ it refers to tall forest for Cockscomb and

5 El Edén, and Atlantic forest for Angatuba; Short forest/cerrado= it refers to short forest for El

6 Edén and cerrado vegetation for Angatuba.

Variable

Study area

Angatuba

Cockscomb

El Edén

Observed Available Observed Available Observed Available

\begin{tabular}{ccccccc}
\hline $\begin{array}{c}\text { Path width } \\
\text { N }\end{array}$ & 49 & 268 & 96 & 280 & 70 & 181 \\
\hline Mean \pm SD & $3.0 \pm 0.61$ & $3.5 \pm 1.69$ & $1.7 \pm 0.59$ & $2.5 \pm 2.69$ & $1.7 \pm 0.87$ & $2.3 \pm 0.83$ \\
& & & & & & \\
\hline $\mathrm{t}$ student & $\mathrm{t}=1.95, \mathrm{P}=0.052$ & $\mathrm{t}=2.97, \mathrm{P}=0.003$ & $\mathrm{t}=5.13, \mathrm{P}<0.001$
\end{tabular}

\begin{tabular}{|c|c|c|c|c|c|c|}
\hline Path use (\%) & & & & & & \\
\hline $\mathrm{N}$ & 51 & 295 & 97 & 280 & 72 & 198 \\
\hline Abandoned & 7.8 & 13.9 & 0 & 0 & 16.7 & 36.4 \\
\hline Rare & 92.2 & 82.4 & 37.1 & 63.6 & 63.9 & 34.8 \\
\hline Frequent & 0 & 3.7 & 62.9 & 36.4 & 19.4 & 28.8 \\
\hline $\mathrm{X}^{2}$ test & $\mathrm{X}^{2}=$ & $=2$ & $X^{2}=$ & $\mathrm{df}=2$ & $\mathrm{X}^{2}=1$ & \\
\hline
\end{tabular}

\section{Path cleaning (\%)}

$$
\mathrm{N}
$$

97

280

74

197 


\begin{tabular}{ccccccc}
\hline Yes & ND & ND & 100 & 100 & 90.5 & 75.1 \\
\hline Not & ND & ND & 0 & 0 & 9.5 & 24.9 \\
\hline \multirow{2}{*}{$\mathrm{X}^{2}$ test } & & - & & & - & \\
\end{tabular}

\begin{tabular}{|c|c|c|c|c|c|c|}
\hline \multicolumn{7}{|c|}{ Vegetation type (\%) } \\
\hline $\mathrm{N}$ & 53 & 302 & 97 & 277 & 73 & 201 \\
\hline Savanna & - & NA & - & NA & 1.3 & 6.0 \\
\hline $\begin{array}{c}\text { Talk/Atlantic } \\
\text { forest }\end{array}$ & 56.6 & 6.0 & 100 & 98.9 & 13.7 & 1.5 \\
\hline $\begin{array}{c}\text { Secundary } \\
\text { forest }\end{array}$ & - & NA & - & NA & 67.1 & 84.6 \\
\hline $\begin{array}{c}\text { Short } \\
\text { forest/cerrado }\end{array}$ & 22.6 & 9.3 & - & NA & 17.8 & 8.0 \\
\hline Edge & 18.7 & 52.6 & & 1.1 & - & NA \\
\hline Plantations $^{1}$ & 1.9 & 32.1 & - & NA & - & NA \\
\hline$X^{2}$ test & $\mathrm{X} 2=1$ & $\mathrm{df}=3$ & & & $\mathrm{X} 2=$ & $\mathrm{df}=3$, \\
\hline
\end{tabular}

\begin{tabular}{ccccccc}
\hline Vegetation height (m) \\
\hline $\mathrm{N}$ & 53 & 264 & 95 & 280 & 73 & 198
\end{tabular}

\begin{tabular}{ccccccc}
\hline Mean \pm SD & $11.2 \pm 3.63$ & $14.1 \pm 4.11$ & $16.7 \pm 3.73$ & $14.7 \pm 2.86$ & $9.8 \pm 3.89$ & $8.5 \pm 3.69$ \\
\hline $\mathrm{t}$ student & $\mathrm{t}=4.74, \mathrm{p}<0.001$ & $\mathrm{t}=5.46, \mathrm{p}<0.001$ & $\mathrm{t}=2.58, \mathrm{p}=0.010$ \\
\hline \multicolumn{2}{l}{ Vegetation cover $(\%)$} & & & & \\
\hline $\mathrm{N}$ & 53 & 267 & 97 & 280 & 73 & 198 \\
\hline
\end{tabular}




\begin{tabular}{|c|c|c|c|}
\hline Mean \pm SD & $3.6 \pm 0.77$ & $3.7 \pm 0.47$ & $3.8 \pm 0.77$ \\
\hline t student & $\mathrm{t}=4.80, \mathrm{p}<0.001$ & $\mathrm{t}=0.18, \mathrm{p}=0.855$ & $\mathrm{t}=0.34, \mathrm{p}=0.735$ \\
\hline
\end{tabular}

7

$8 \quad{ }^{1}$ It included eucalyptus and pine plantations

$9{ }^{2}$ We performed the test despite $20 \%$ of the expected values are less than 5 in order to not lost the 10 biological interest of data.

11 


\section{Table 4 (on next page)}

Identification of faeces and urine on scrapes

Felid species and sex determined for faeces or urine found on scrapes in different study areas. $\mathrm{F}=$ female, $\mathrm{M}=$ male, $\mathrm{ND}=$ sex non-determined. 
1 Table 4. Felid species and sex determined for faeces or urine (the only one with asterisk) found

2 on scrapes in different study areas. $\mathrm{F}=$ female, $\mathrm{M}=$ male, $\mathrm{ND}=$ sex non-determined.

\begin{tabular}{|c|c|c|c|}
\hline Study area & \multicolumn{2}{|l|}{ Faeces from scrapes } & \\
\hline & Jaguar & Puma & Ocelot \\
\hline Virua & $1 \mathrm{~F}, 1 \mathrm{M}$ & $1 \mathrm{M}$ & - \\
\hline El Zapotal & - & $1 \mathrm{M}$ & - \\
\hline Los Ocotones & $1 \mathrm{M}, 1 \mathrm{ND}$ & - & - \\
\hline La Cojolita & - & $1 \mathrm{ND} *$ & - \\
\hline El Edén & $12 \mathrm{M}$ & $2 \mathrm{M}$ & - \\
\hline Serra das Almas & - & $4 \mathrm{M}$ & - \\
\hline Cockscomb & $4 \mathrm{M}, 1 \mathrm{ND}$ & & - \\
\hline Angatuba & & $1 \mathrm{M}$ & $1 \mathrm{~F}$ \\
\hline
\end{tabular}




\section{Figure 1}

Types of large felid scrapes.

Examples of scrapes with different sizes and on different substrates. $A, b$ and $c$ are puma scrapes from Angatuba and the other ones could be from pumas or jaguars, although $d$ and $f$ could be from jaguar since they are much longer than wider and no marks from the two legs (see text for details). Mark of claws of both legs (even back leg foot tracks) are clearly appreciated in a and e scrapes. The pile of dirt on the end of the scrape is marked in all cases, and in $a$ and $b$ how length and width were measures indicated as well (note than $b$ is one case where length and width was similar). Photos by Francisco Palomares. 


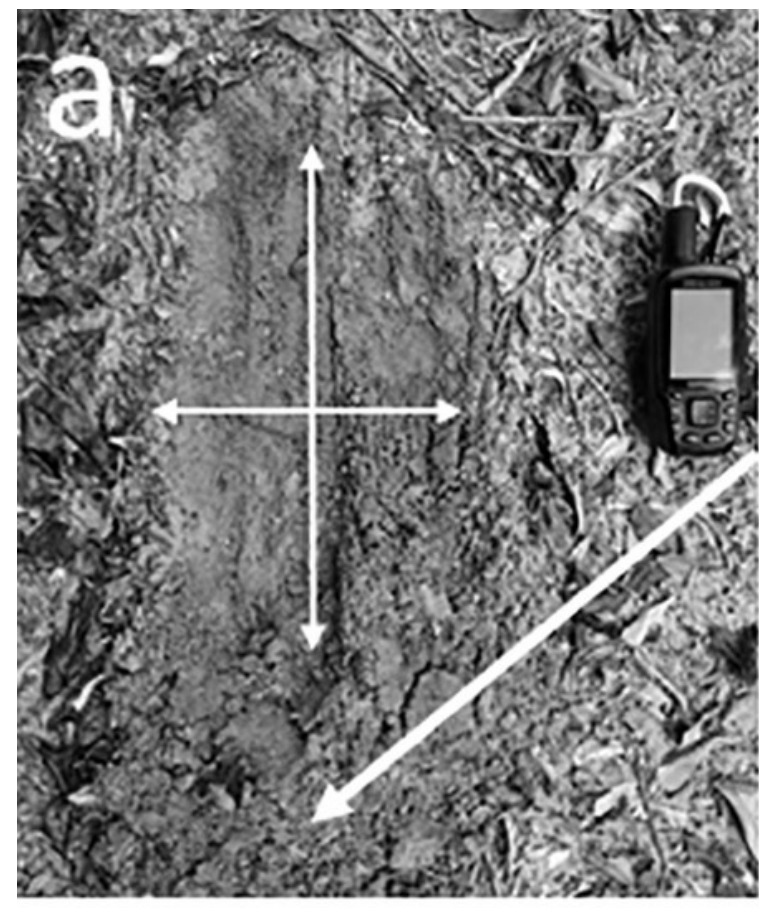

\section{Dirt pile}

\section{Dirt pile}
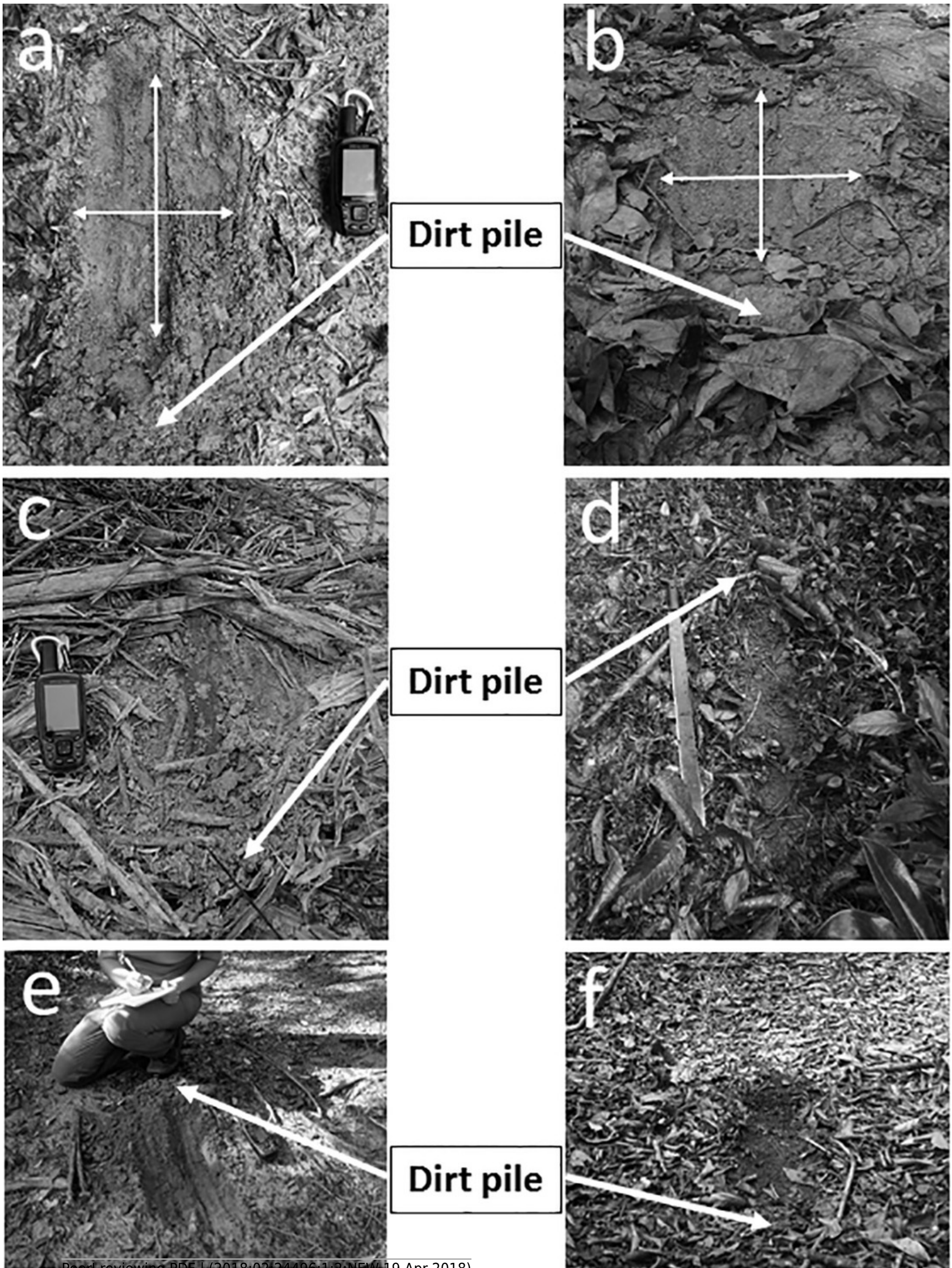

\section{Dirt pile}
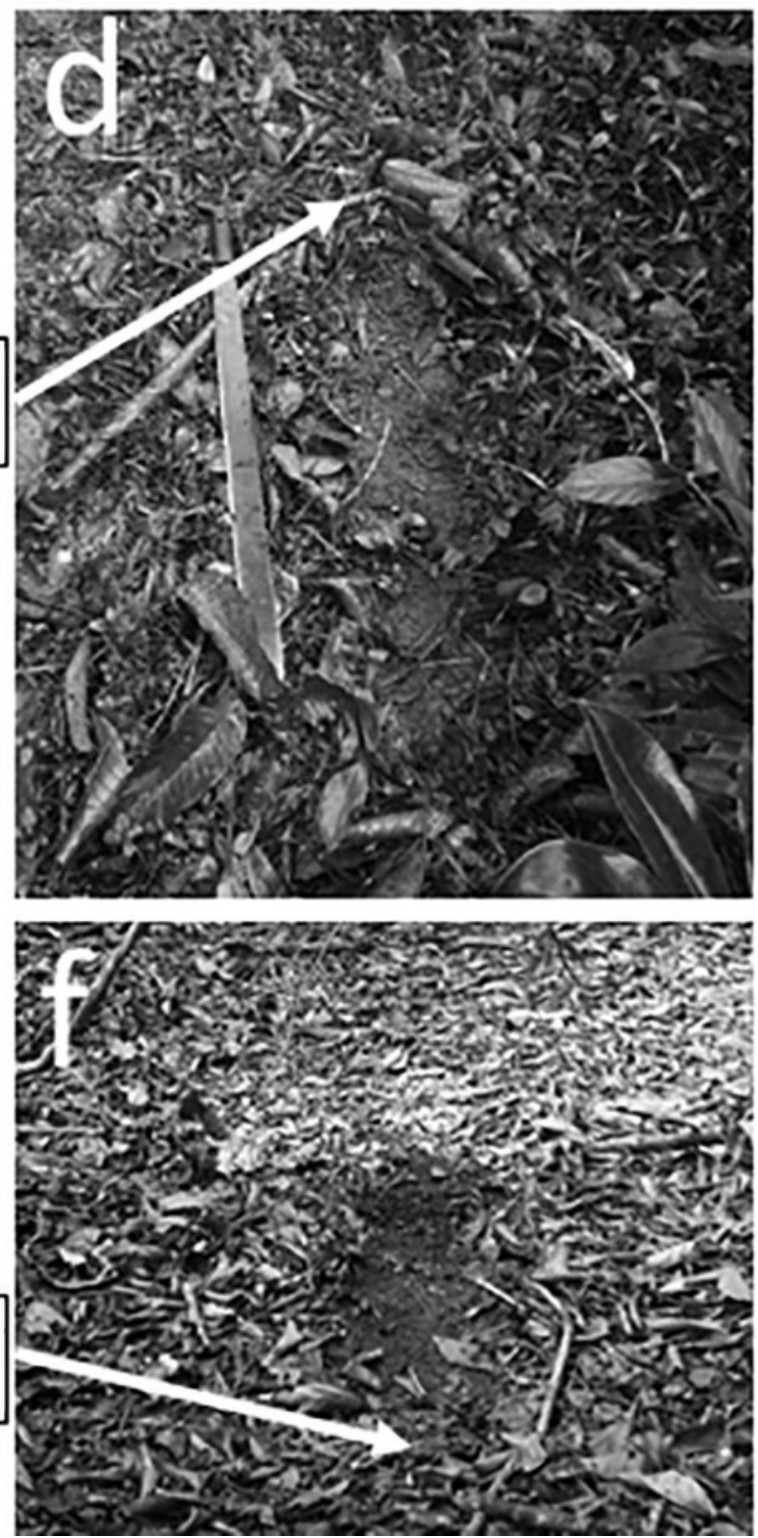
Figure 2

Main study areas and surveys.

Sketch of the principal study areas (Angatuba, Cockscomb, El Edén and Serra das Almas), tracks surveyed (lines) and total scrapes found (points). Details of San Ignacio study area is not showed since only two scrapes were found, and on the general map the location of other areas where we obtained extra information used in this study are indicated with numbers (see "Felid relative abundance and assigning scrapes to species and sex" section).

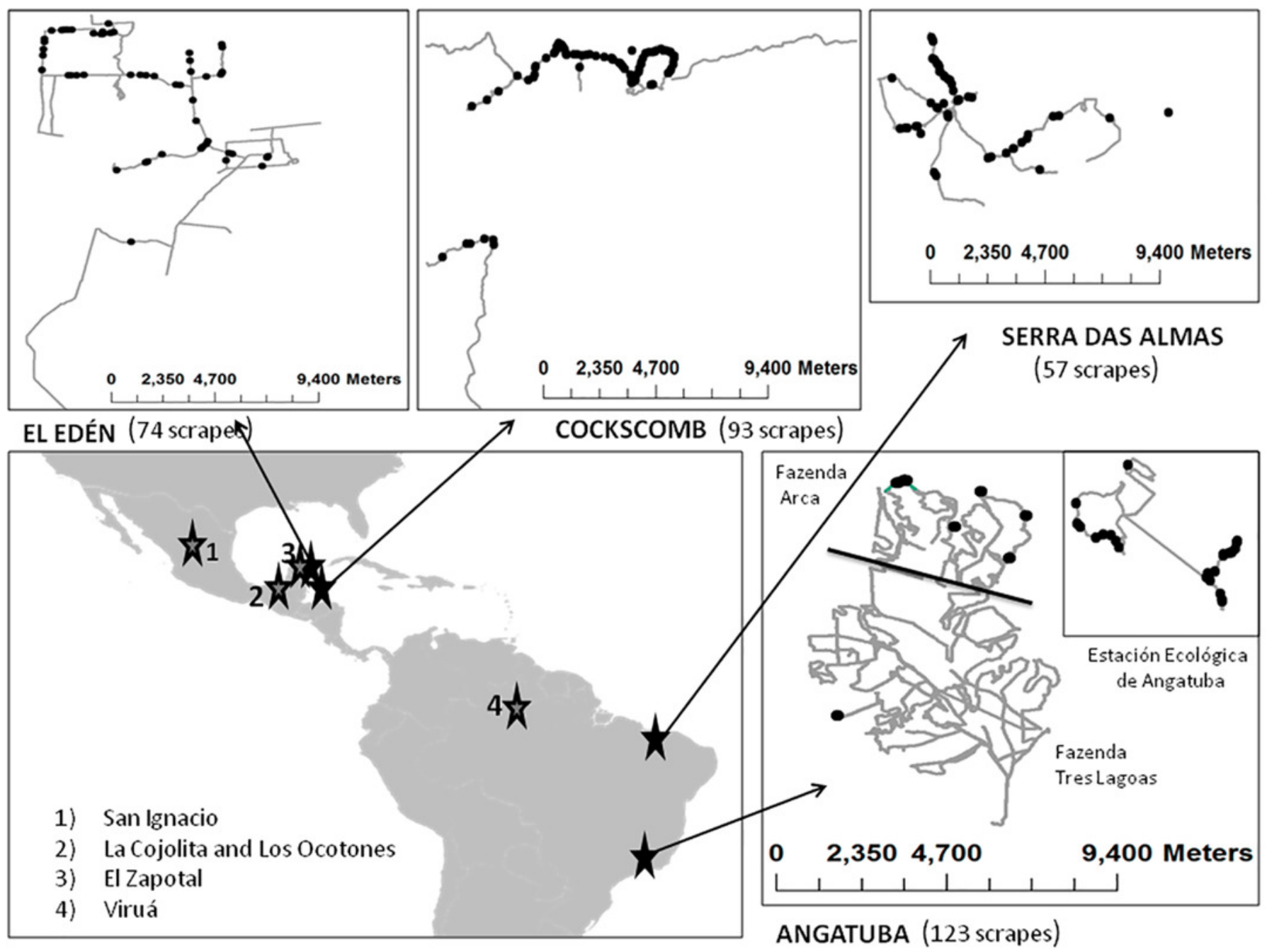




\section{Figure 3}

Intensive scraping points of pumas.

Sketch of the two intensive scraping points (ISA1 and ISA2) found after following a puma track in Angatuba study area during the survey of 2012. Aerial images obtained from Google Earth.

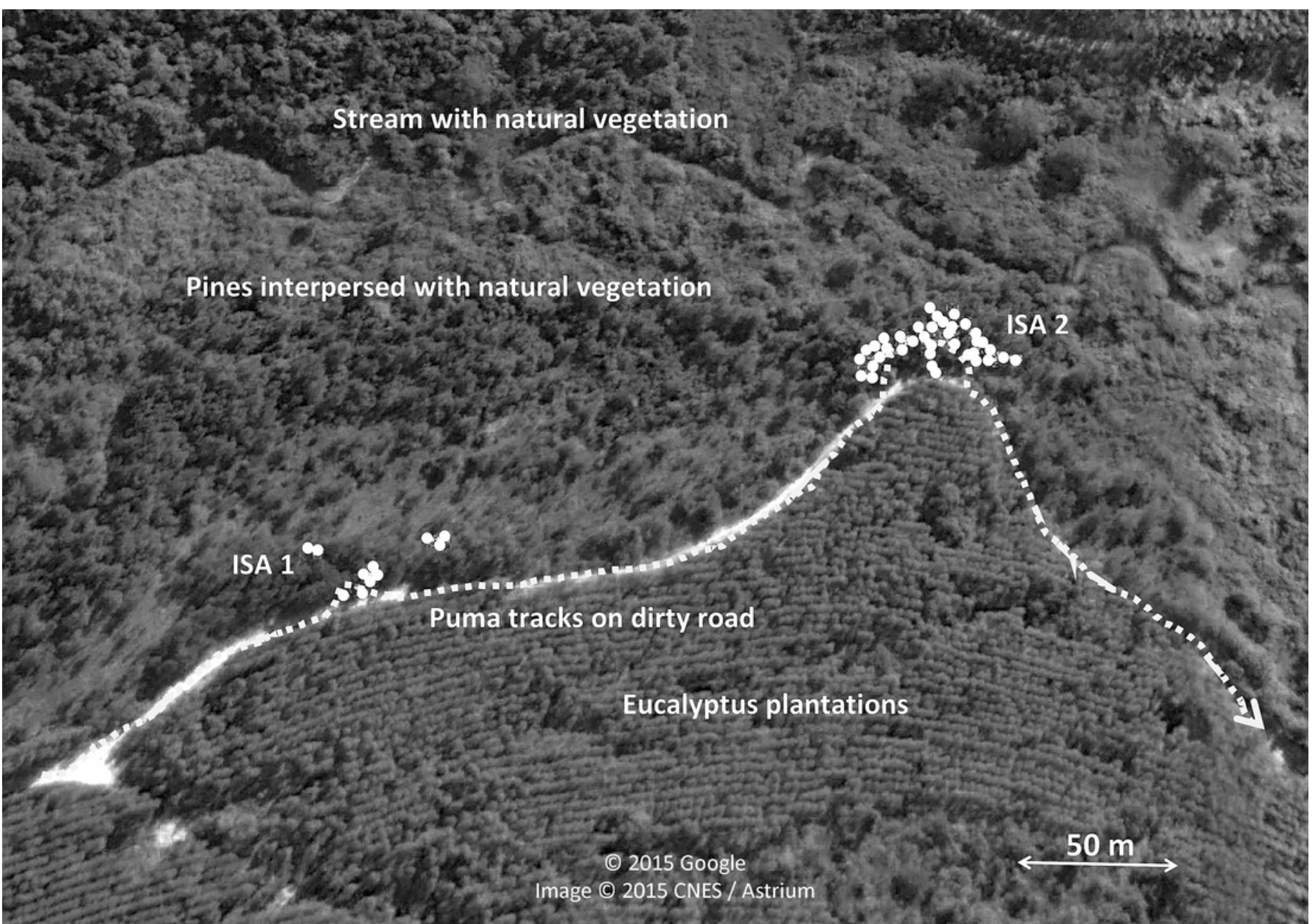


Figure 4

Position of scrapes on paths.

Frequency distribution of the position of the scrapes on trails $(A)$ and car tracks $(B)$ in Angatuba, Cockscomb, El Edén, Serra das Almas and overall. There were no scrapes on trails in Angatuba and on car tracks in Serra das Almas.

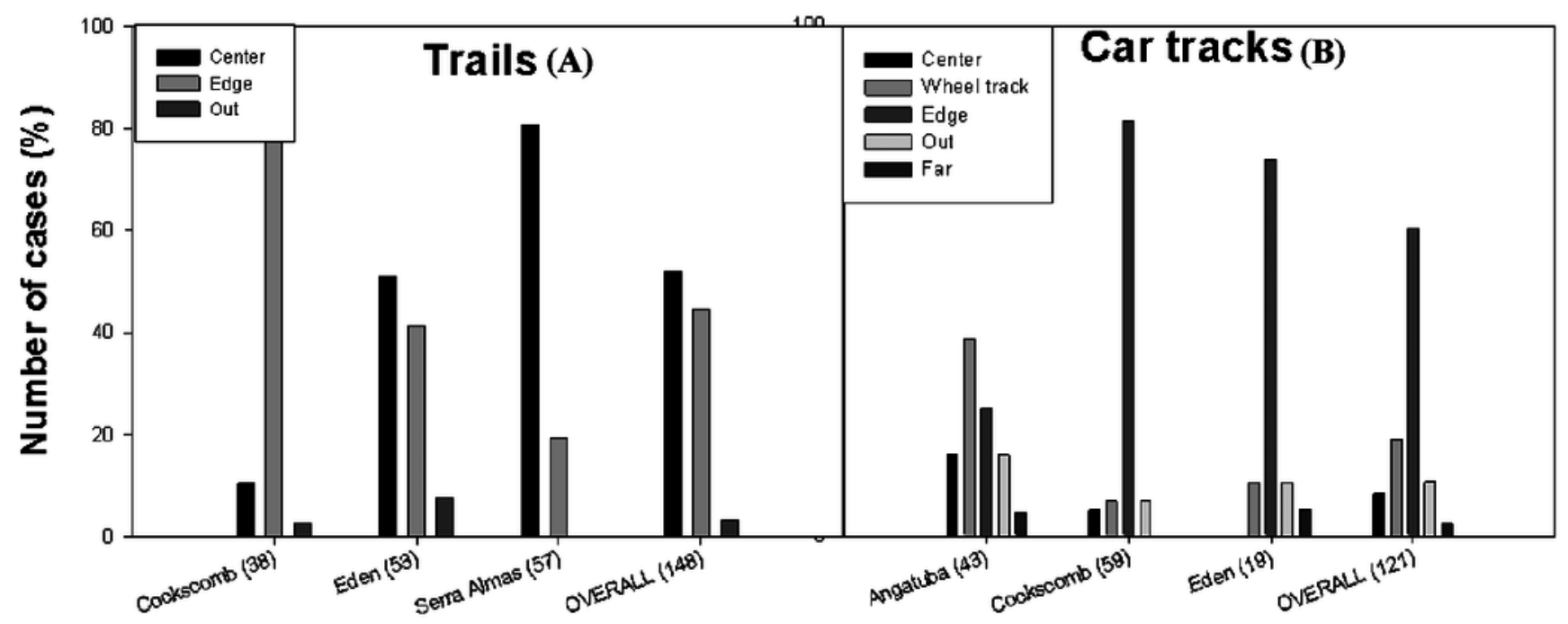

Study areas

Study Areas 
Figure 5

Re-scraping behaviour.

Mean and standard deviation of the number of scrapes found on the same sites (i.e. $<22 \mathrm{~m}$ between scrapes) in each study area.

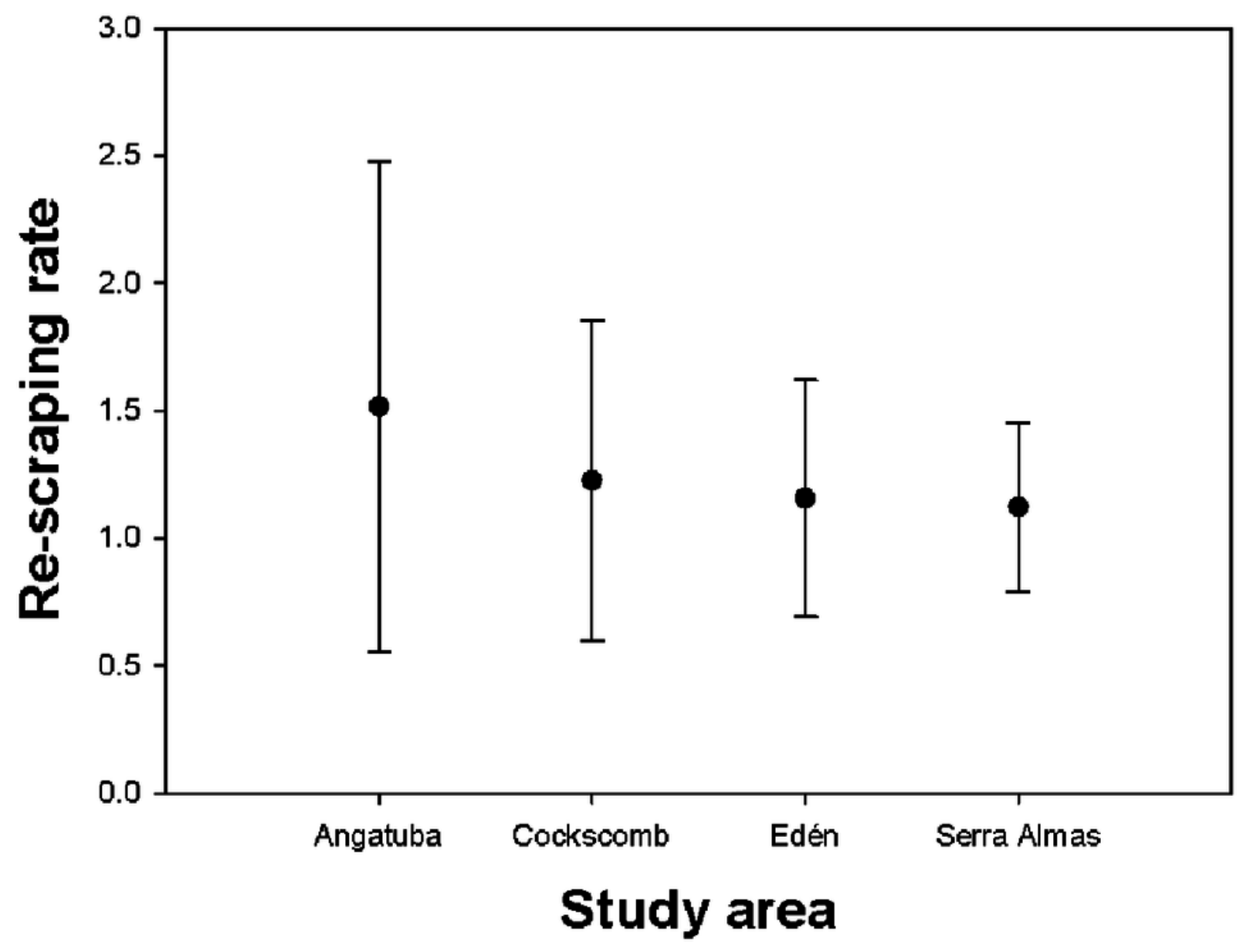




\section{Figure 6}

Lineal distribution of scrapes on paths.

Estimates of the Ripley's reduced second moment functionK(r), with the translation correction of Ohser (1983), from a point pattern of scrapes in trails sampled in each study area (A-E). The gray shadow represents the expected distribution of scrapes following 1000 random distributions (see text for details). The black line show the observed distribution of distances between consecutive scrapes. When the line is above the shadow area indicates that scrapes are close together than expected by random. 

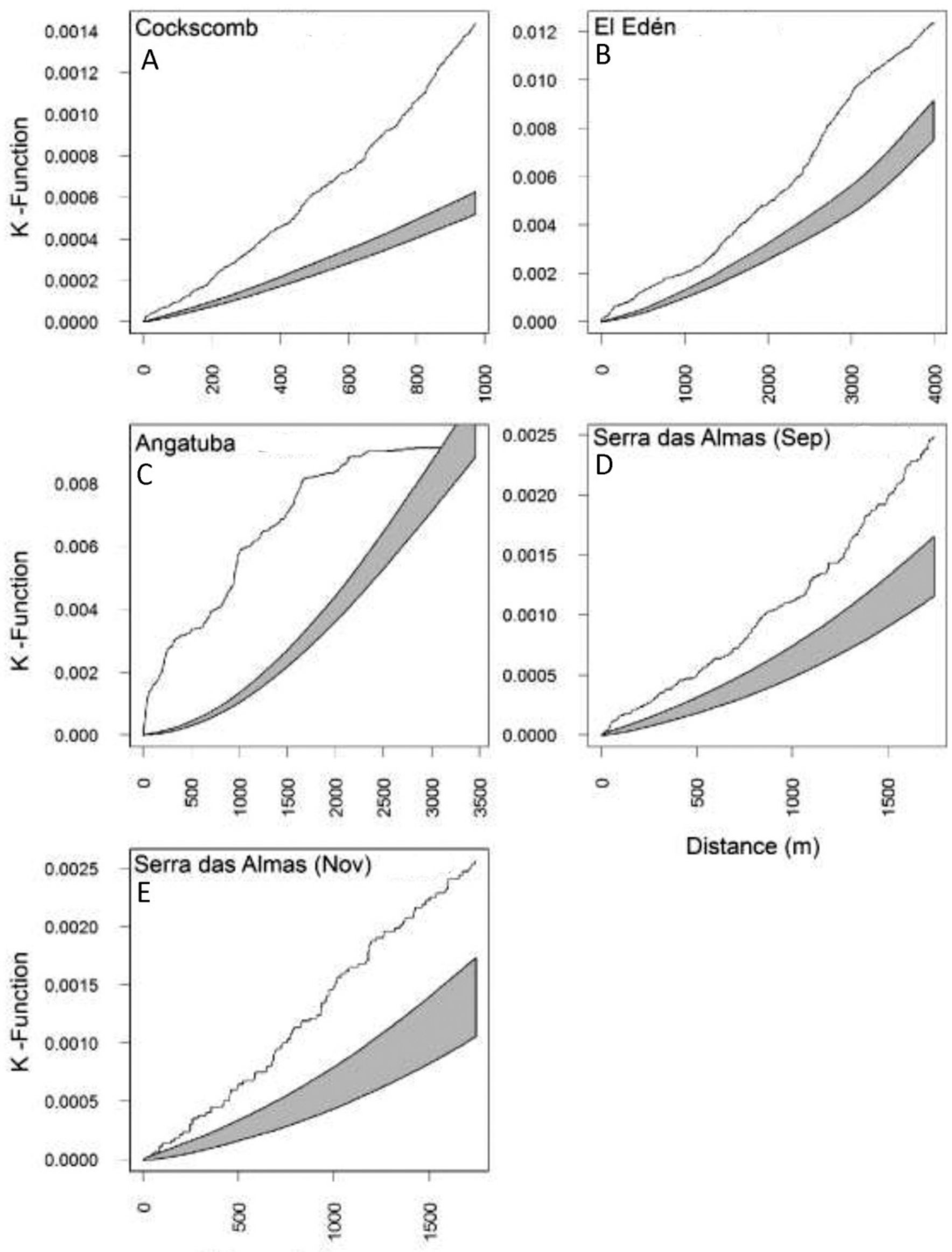

Distance $(\mathrm{m})$ 


\section{Figure 7}

Lineal distance between consecutive scrapes.

Frequency distribution of distances between scrapes on linear paths for all data altogether and for every study area. There were significant differences between study areas $\left(X^{2}=\right.$ 33.202, d.f. $=9, P<0.001$ ), and also between all pair wise comparisons (all $X^{2}>8.53$, d.f. $=$ 3, all $P<0.036)$, except between El Edén and Serra das Almas $\left(X^{2}=3.605\right.$, d.f. $=3, P=$ $0.307)$.

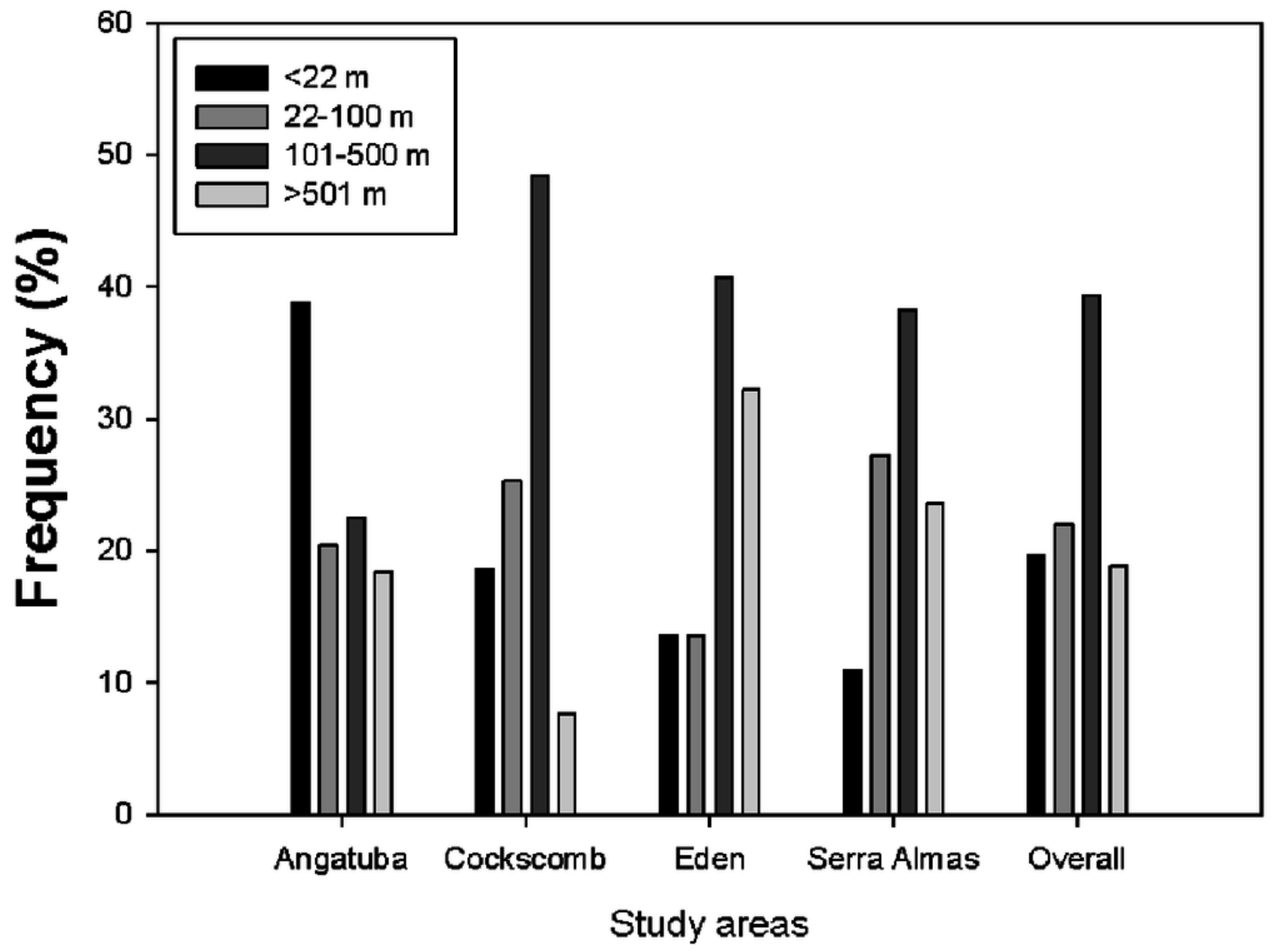




\section{Figure 8}

Lenght and width of scrapes.

Box plots show differences in length (A), width (B) and ratio between length and width (C) for scrapes sizes from three study areas. The box indicates the 25th and 75th percentiles, a line within the box marks the median; error bars indicate the 90th and 10th percentiles, and point values outside the last percentiles (outsiders). 

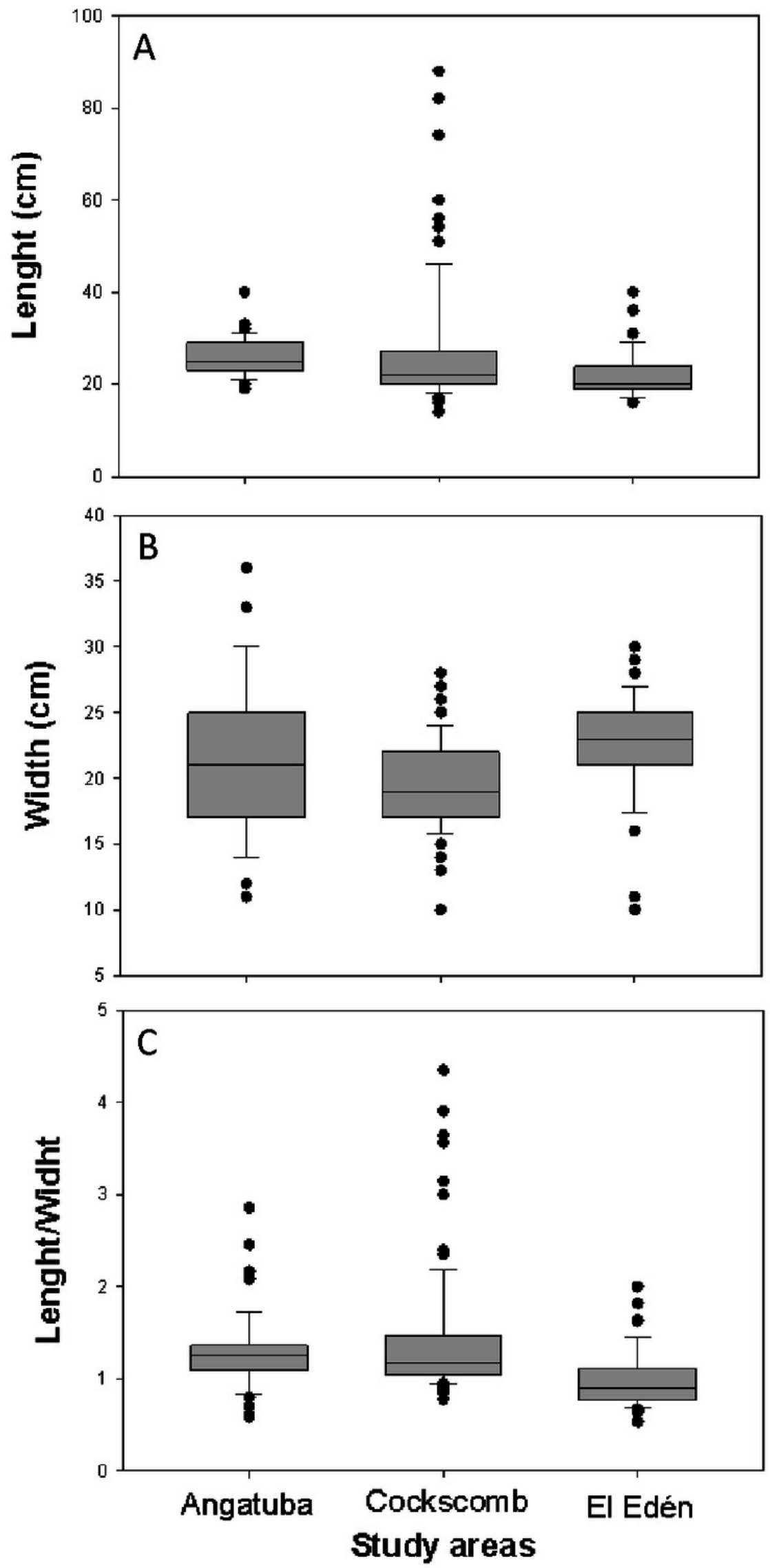